\title{
Response with Particle $n e$ in Japanese and Its Relation to wakimae as a Cultural Context: A Discourse Analysis on Culture in Conversation
}

\author{
Filia, Njaju Jenny Malik, and Untung Yuwono
}

\begin{abstract}
This paper discusses responses with particle ne in Japanese conversation and its relation to Japanese culture. It focuses on how Japanese linguistic markers in response used in conversation correspond to culture, called as wakimae. Hence, the understanding of the wakimae influences response realization. By using the qualitative method, this research uses 30 video-taped Japanese talk shows as data. In Japanese linguistics, particle ne known as particle confirmative. It means, speaker believes that hearer knows well than speaker, and then speaker confirm to hearer. But why in giving response, hearer (who become next speaker) needs to use particle ne? The use of particle ne in response has opposite meaning to confirmatory function. Particle $n e$ implies that the speaker who are in the territory of information. In the same time, speaker engages hearer because of alignment and respect. Particle $n e$ in response shows wakimae, the norm that are expected to be obeyed by Japanese speaker. This characteristic of response is not only ruled by speaker's intention but also by cultural values. These cultural values become important consideration for a speaker to choose utterances of response. Therefore, the notion of wakimae can explain the utterance choice from the perspective of cultural context.
\end{abstract}

Index Terms-Conversation, response, cultural context, wakimae.

\section{INTRODUCTION}

The characteristics of response in a language is interesting to study because a response is not only determined by the idea to be uttered, but also by cultural values that exist in the community of the speakers of the language. A cultural context is taken into consideration in the selection of the utterance to respond. In Japanese the particle $n e$ is known as a confirmative particle (Moriyama, 2003; Iori, 2001). As a confirmative particle, the use of the particle $n e$ in an utterance shows that the speaker assumes that the addresee has better information than the speaker does. Therefore, the speaker feels the need to ask for confirmation from the addressee. In conversations observed, it appears that the use of the particle ne in the response shows a different meaning from its semantic meaning. This can be seen in the following sample responses.

\section{(1)}

\{The topic of the conversation is fertility treatment. OT (guest) responded to the utterance of UY (host).\}

$$
\text { UY：え：：ゲスト皆さん(.)この不妊 }
$$

Manuscript received September 12, 2016; revised December 9, 2016.

The authors are with the University of Indonesia, Indonesia (e-mail: filiagogo@yahoo.com, filia@ui.ac.id).

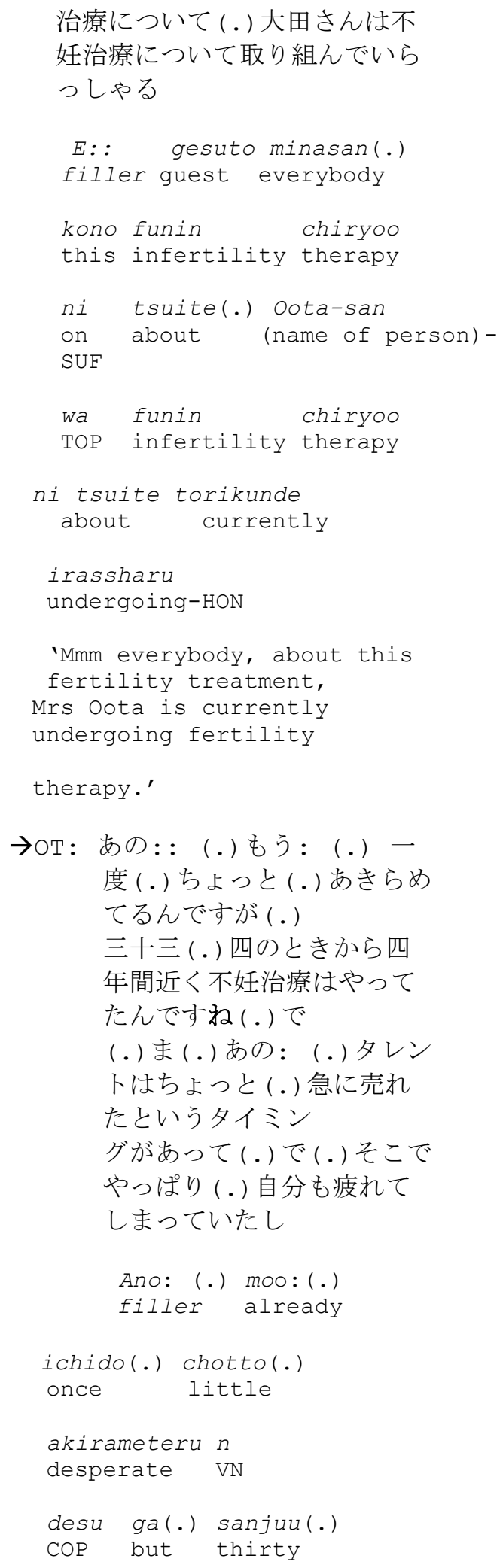




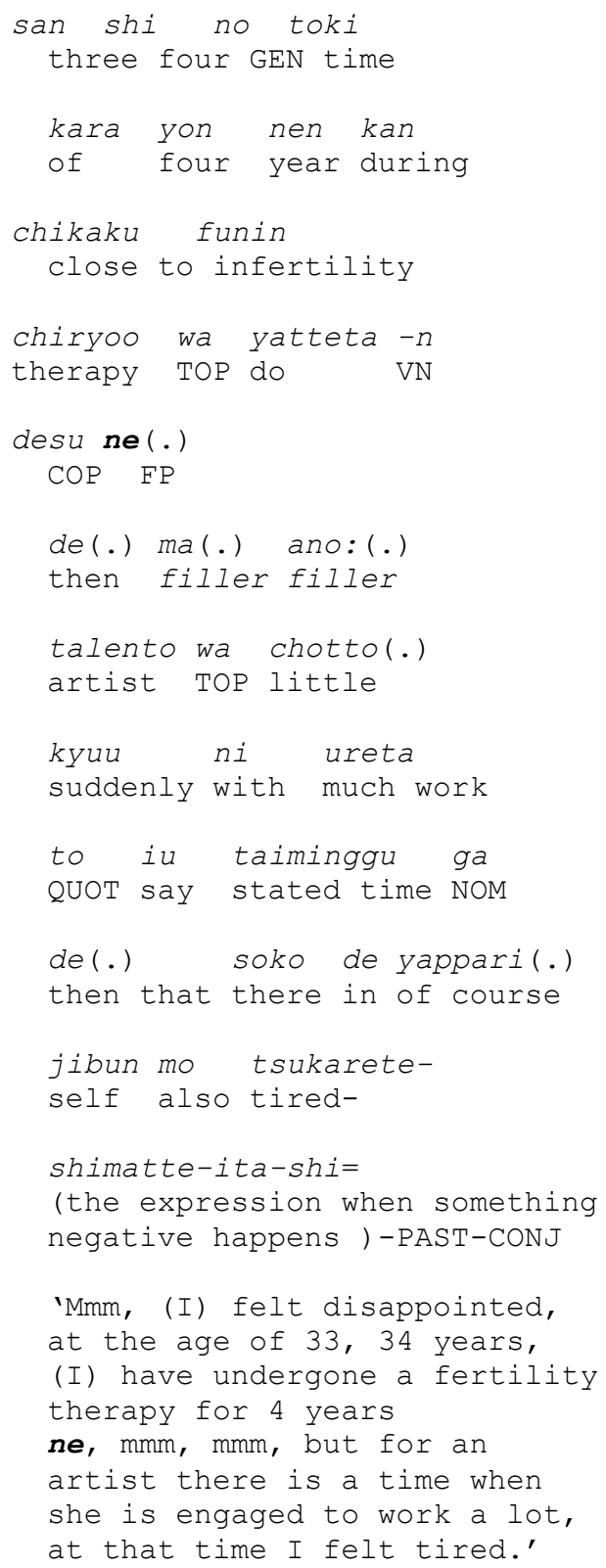

In his response OT used the particle ne. The particle ne here does not seem to have a confirmatory meaning. What is the meaning of the particle ne in this utterance? The particle $n e$ is generally used when the speaker assumed that it was the addressee who had the information, so the speaker would confirm it. However, in the context of conversation (1), it is the speaker who had the information. In his response, the speaker was explaining something related to him. Then, does the speaker need to confirm it while it is actually him who had the information? The use of the particle ne beyond its function the confirmative particle associated with the underlying cultural context. This cultural context can be seen from wakimae or the norm which is expected to be followed by the Japanese speaking community. This is the topic of this paper: Responses with the particle ne and its relationship with wakimae as a cultural context.

\section{RESEARCH METHODOLOGY}

The data used in this research was a conversation on the
Asaichi talk show on NHK television in Japan. The reasons for the selection of the materials from Asaichi talk show as a corpus are: (i) the conversations are not scripted and unedited, in which every participant is given the freedom to speak after the host starts the conversation, or in other words, both the host and the guest have the opportunity to respond; (ii) The number of participants of the speech event is more than two persons, so researchers were able to observe how the strategy used in responding; (iii) the topics of conversation vary; they are about real, daily problems of the people.

The type of data used is the responses which use the particle ne. The data is later transcribed and presented in its transliteration and translated using the method of communicative translation. Utterances which use the particles ne are semantically and pragmatically analyzed and and its relation to the cultural context of wakimae is examined.

\section{RESULTS AND ANALYSIS}

Based on the data consisting of 181 stimulus-responses, the number of responses using the particle ne is 54. Some sample responses using the particle ne can be seen in data (2) below.

(2)

$\{\mathrm{YH}$ (host, male) ask YY (guest star, reporter) about small fish affected by radiation.\}

$\mathrm{YH}$ : 今：あの：見つかつたというの は小女子ですね。

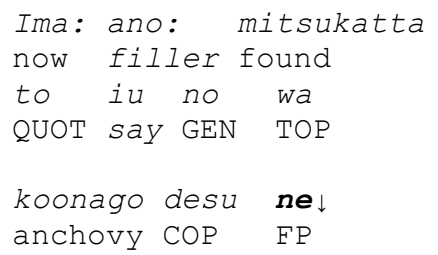

'Now, the achovy has been found, right?'

$\rightarrow Y Y$ : 小女子という生ですね(.)なん か非常に小さな魚でプランクト ンの種族で食べる魚なんですね (.) どうしてもその現象が最初 で放送生物もこれ小さいもの なので(.)ま:プランクトンが 付着したり (.) プランクトンが 取り込んだりする(.) そのプランクトンを最初食べる のは小さな魚ので(.) 魚が出た(.)

あと：小女子はあの：まだ当 然小さい(.)それほど普通の魚 より力がないので(.) 海面の方泳ぐではっしゅでん しょうから出てる水もですね (.)だいぶあの：しんしょうに 


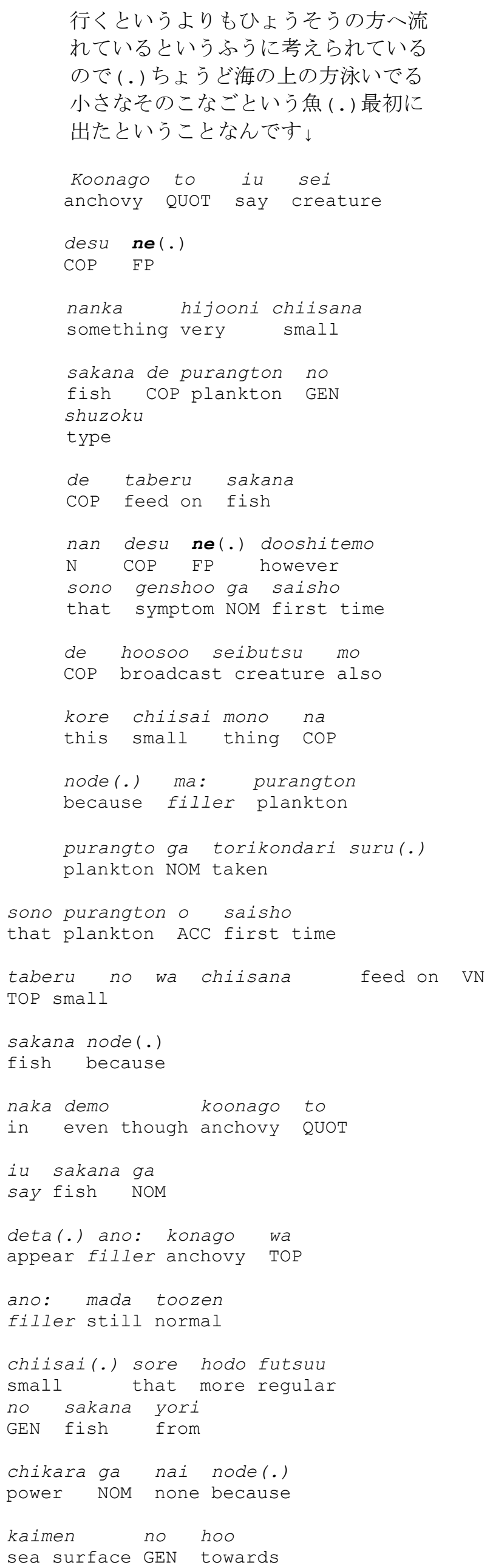

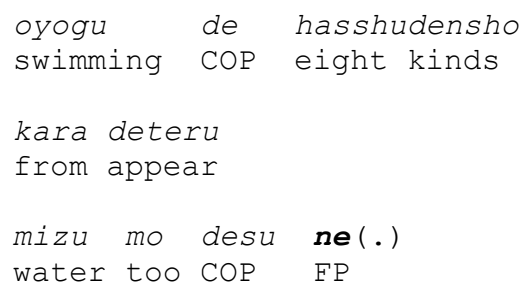

'Anchovy, this very small fish feed on a type of plankton. Since the small fish are on the water surface, it is the small fish that first fed on the plankton (containing nuclear radiation from the Fukushima nuclear power plant). So it just happened to be the first to be taken was the small fish found in the surface of sea water and having fed on plankton which had been exposed to radiation.'

$$
(17: 53-20: 32)
$$

(Appendix 7, AI20110407, pages. 4-5)

The speaker YY began his response by saying koonago to iu sei desu ne 'living thing called koonago (anchovy), right'. The use of the particle $n e$ in this utterance shows the attitude of the speaker who involved the addressee his utterance. This utterance was delivered by the speaker before giving further explanation about koonago. Furthermore, YY said nanka hijoo ni chiisana sakana de purangton no shuzoku de taberu sakana nan desu ne(.) 'What, very small fish, fish that feed on plankton, right'

The use of the particle ne at the end of this utterance shows the attitude of the speakers (including the addresse) in the utterance. It also shows that the speaker was trying to maintain the atmosphere of the conversation with the 
addressee. This is wakimae shown through the linguistic evidence. Actually, it is fine for the speaker to give an explanation without him involving the addresse. However, YY felt the need to take into account the existence of addressee through his utterance. The speaker wanted to create an impression that he would not want to speak alone, so he involved the addressee to cooperate in the conversation. This shows, the speaker had the intention to keep the conversation going. In other words, the particles ne at the end of the utterance implies that the speaker did not have an intention to stop the conversation. The use of $n e$ in the utterance above also implies that the speaker did not want to show the attitude that the information being conveyed only belongs to the speaker. In addition, the particle ne contained at the end of YY's utterance shows that the addressee was given the opportunity to interrupt or give a comment.

The use of the particle ne in the response as explained above implies the attitude of the speaker in accommodating the addressee. The accommodation provided by the speaker are: (i) involving the addressee to, (ii) maintaining the atmosphere of the conversation, (iii) attempting to be in harmony with the addressee, (iv) giving an opportunity to interrupt the addressee. This accommodation is in line with the cultural aspect wakimae. In the concept of wakimae, the speaker is expected to follow certain norms of Japanese community in general. Wakimae expected from the speaker is that the speaker has to be gentle, polite and create a harmony with the addressee (Ide, 2006).

\section{CONCLUSION}

The notion of wakimae (expected norms of Japanese society) that is followed Japanese speakers can be seen in their use of linguistic evidence in the form of the particle ne in giving a response. Its use in a response to a stimulus shows the giving of accommodation from the speaker to the addressee. This accommodation is considered proper and appropriate because the speaker should give affection to the addressee through an utteance. The accommodation implied by the use of particles are (i) the effort to involve the addressee in the speaker's utterance, (ii) the effort to maintain the atmosphere of conversation, (iii) the effort to be in harmony with the addressee, (iv) the effort to provide the addressee with the opportunity to interrupt. This is what is expected from the Japanese society as they are represented by the addressee in this context.

\section{ACKNOWLEDGEMENT}

We would like to thank University of Indonesia as financial sponsor that support us for research in linguistic field from cultural context.

\section{REFERENCES}

[1] J. L. Austin, How to Do Things with Words, Oxford New York: Oxford University Press, 1962.

[2] M. L. Bigge, "A Relativistic definition of stimulus-response Dalam," Journal of Educational Psychology, vol. 46, no. 8, pp. 457-464, 1955.

[3] B. J. Birner, Introduction to Pragmatics, Singapore: Wiley-Blackwell Publication, 2013.

[4] P. Brown and S. Dan Levinson, Politeness: Some Universals in Language Usage, Cambridge University Press, 1987.
[5] P. Brown, "Questions and their responses in Tzeltal," Journal of Pragmatics, vol. 42, pp. 2627-2648, 2010.

[6] K. Bühler, "Theory of language: The representational function of language," John Benjamins Publishing Company, pp. 33-68, 1984.

[7] A. V. Cicourel, "On John R. Searle's intentionality," Journal of Pragmatics, vol. 11, pp. 641-660.

[8] J. W. Creswell, Research Design: Qualitative, Quantitative, and Mixed Methods Approaches, Thousand Oaks California: Sage Publication, 2009.

[9] A. D. Cruse, Meaning in Language, Oxford: Oxford University Press, 2004.

[10] J. Cutting, Pragmatics and Discourse, London \& New York: Routledge, 2002.

[11] W. A. Davis, Implicature: Intention, Convention and Principle in the Failure of Gricean Theory, Cambridge: Cambridge University Press, 1998.

[12] S. Eggins and D. Dan Slade. Analysing Casual Conversation, London: Continuum, 2001.

[13] P. Grice, Logic and Conversation, William James Lectures, Harvard University Press, 1975.

[14] M. Hayashi, "An overview of question-response system in Japanese," Journal of Pragmatics, vol. 42, pp. 2685-2702, 2010.

[15] S. Ide, Wakimae no Goyoron, Tokyo: Taishukan Shoten, 2006.

[16] I. Iori, Atarashii Nihongo Gaku Nyuumon, Suriie Nettowaaku, 2001.

[17] T. Moriyama, Koko Kara Hajimaru Nihongo no Bunpo, Hitsuji Shoboo, 2003.

[18] T. Stivers, "An overview of the question-response system in American conversation," Journal of Pragmatics, vol. 42, pp. 2772$2781,2010$.

[19] T. Stivers and N. J. Enfield, "A coding scheme for question-response sequences in conversation," Journal of Pragmatics, vol. 42, pp. 26202626, 2010.

[20] J. Thomas, Meaning in Interaction: An Introduction to Pragmatics, London \& New York: Longman, 1995

[21] M. Usami, Discourse Politeness in Japanese Conversation, Tokyo: Hitsuzi Syobo, 2002.

[22] R. Watts, Politeness, Cambridge: Cambridge University Press, 2003.

[23] D. Wilson and D. Sperber, "Inference and Implicature" dalam Pragmatics, New York: Oxford University Press, 1991.

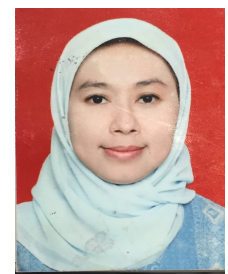

Filia is a lecturer at the Japanese Studies program, Faculty of Cultural Sciences. She was born in Jakarta, January 29, 1979. She completed her undergraduate education in 2002 and magister program in 2006 at University of Indonesia. She is interested in semantics and pragmatics. She is currently completing linguistic doctoral program at University of Indonesia.

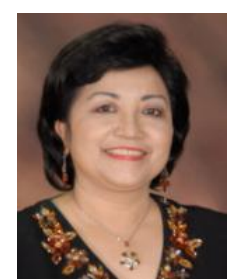

Njaju Jenny Malik Tomi Hardjatno is a lecturer at the Faculty of Cultural Sciences at University of Indonesia. She was born in Jakarta, October 23, 1954, gaining bachelor of literature degree from Faculty of Literature (Faculty of Letters UI) majoring in Russian, in 1979 and getting magister degree from UI postgraduate program majoring in anthropology Linguistics, in 1989.

She later prepared her dissertation by doing some researches in Moscow, under the guidance of a professor from MGU (Moscow State University) in Moscow, Russia and became the First Indonesian Doctor on Russian Linguistics from UI Postgraduate Program, Linguistics Study Program, 1998 and her dissertation entitled the Analysis of Russian Advertising Language: Advertisement as a New Phenomenon of Mass Information in Russian Society.

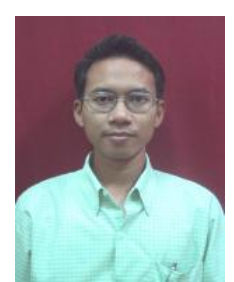

Untung Yuwono is a lecturer at the Indonesian Studies Program (Undergraduate) and Linguistics Study Program (Graduate Program), Faculty of Cultural Sciences, University of Indonesia (FIB UI). He completed his undergraduate education in 1996 at the Indonesian Literature Department, Faculty of Letters, University of Indonesia (FIB UI now).

In 1999, he continued his doctoral studies in Linguistics Studies Program, FIB UI, through the "fast - track" and finished his studies in 2004 with a dissertation entitled " Construction Asindetis in Indonesian Sentence". He is interested in the field of study of discourse, morphology, syntax, semantics, and the teaching of Indonesian language as a foreign language. 